\title{
Thermal Surface Analysis on Neo-minimalist apartment façades in Penang, Malaysia
}

\author{
Yasser Arab ${ }^{1,1}$ Ahmad Sanusi Hassan ${ }^{1}$, and Bushra Qanaa $^{2}$ \\ ${ }^{1}$ School of Housing, Building, and Planning. Universiti Sains Malaysia \\ ${ }^{2}$ Faculty of Architecture, Ittihad Private University
}

\begin{abstract}
The study investigates apartment's façade thermal performance with neo-minimalist architectural style in Penang, Malaysia. Neo-minimalist style is considered as the most popular style in Malaysia in 2010s. The style is rediscovering from early modern minimalist movement with a design concept "less is more". It applies minimal and efficient design of architectural character in defining form and space. Penang Island the second most important city in Malaysia after Kuala Lumpur. It is located at the north-western part of the country. The first case studies is the Light Linear apartment which has sixteen stories located on the east cost of Penang Island at Pantai Street, Penang. The second case study is BayStar apartment building, the eleven stories building tis located in Bayan Lepas at the seaside facing Jerejak Island. In order to conduct this study Fluke Ti20 thermal imager was used to capture thermal images for the west facades of the selected case study hourly from 12:00 to 6:00 $\mathrm{pm}$ on $15^{\text {th }}$ March 2017. The study finds that the recessed wall, balconies and the shading devices were the important elements to provide shades on the façades for good thermal performance.
\end{abstract}

\section{INTRODUCTION}

The study aims to investigate the façade surface temperature of two neo-minimalist architecture style highrise buildings within Penang Island, Malaysia. The two selected case studies are located in the eastern part of Penang Island, Malaysia with longitude $100.3288^{\circ} \mathrm{E}$ and latitude $5.4142^{\circ} \mathrm{N}$. Penang is considered the second most important state in Malaysia [1, 2], and it has experienced rapid development in the last three decades [3]. High-rise buildings have been built in Malaysia since the 1970s. Lately, high-rise buildings have become a popular residential building type in Malaysia because of the ability to provide the required high number of dwelling units [4]. A 2010 study by the Department of Statistics Malaysia found that over 2 million people live in high-rise apartment buildings in Malaysia, and this number has been increasing rapidly in the last 2 decades [5] (Figure 1).

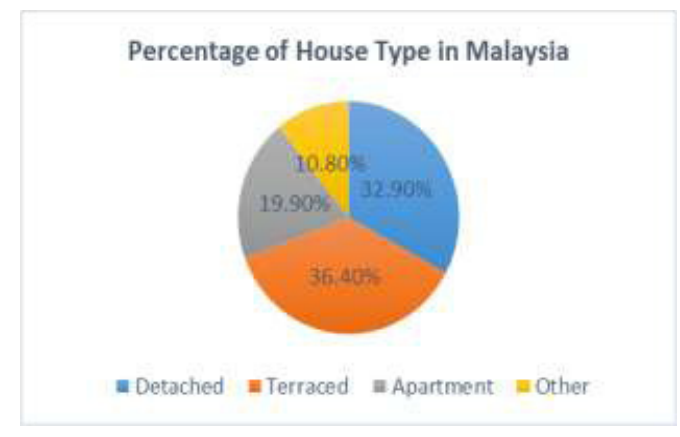

Fig.1. Houses types ratio in Malaysia.

\footnotetext{
${ }^{1}$ Corresponding author: yasserarab2005@yahoo.com
} 


\section{PROBLEM STATEMENT}

Energy consumption is considered one of the most important issues that scholars are trying to solve and reduce. In countries with tropical climate such as Malaysia, it is very important to have an excellent façade design to be able to provide sufficient shading performance and prevent unnecessary solar radiations from penetrating into the house [6-8]. When the building façade is exposed to direct sunlight which is the case for many buildings, it has a problem of transferring the heat from outside wall to the indoor area of the building. The high amount of unnecessary solar radiation causes heat gain inside the building which leads to uncomfortable thermal conditions due to the temperature increase which growths the usage of air-conditioning to cool down indoor area [9-11].

\section{CASE STUDIES}

The first selected case study is The Light Linear. The sixteen stories building is located on the east coast of Penang Island at Pantai Street, Penang (Figure 2). While the second selected case study is BayStar apartment which is eleven stories tall and is located by the seas, facing Jerejak Island in Bayan Lepas. Both selected case studies have neo-minimalist architectural style, and they are built for high-income families (Figure 3)

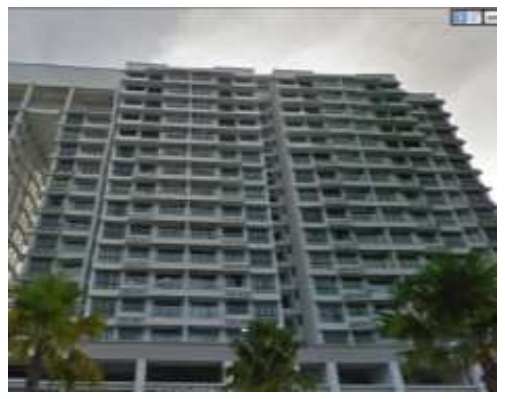

Fig. 2 The light Linear Condominium

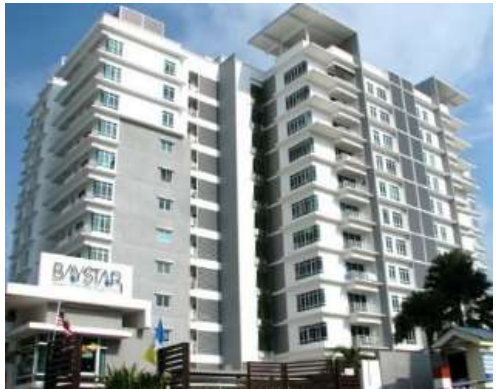

Fig. 3 Baystar Condominium

\section{METHODOLOGY}

This research is based on field study. It involves snapping thermal images of the west façade for the two selected case studies. The thermal images were taken by thermal camera known as Fluke Ti20 thermal imager (Figure 4). The thermal images were snapped hourly base from 12:00 to 6:00 pm on 15th March 2017 [12].

The Fluke Ti20 is an infrared camera which is able to take images with thermal information that can provide the temperature of every point of the building façade [13]. To analyse the thermal images taken by the Fluke Ti20, the images were then exported into SmartView ${ }^{\circledR}$ computer software which comes with the Fluke device. This software has tools to help the researcher to analyse the images and the results, and produces photos with infrared and digital images together to provide all the required information in a very easy way to perform the analysis [14, 15] (Figure 5). 


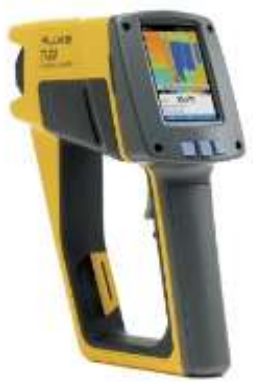

Fig. 4. Fluke Ti20 thermal imager

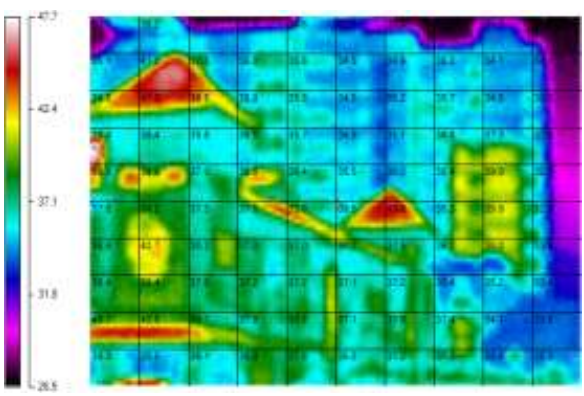

Fig. 5. An example of an infrared image

\section{RESULTS ANALYSES}

Three limitations were involved in this study, the first limitation is that the study was conducted in the afternoon hours as mentioned earlier (from 12:00 to 6:00 pm), and this was because the sunlight during the morning hours is not as intense as during the afternoon hours, and is more important to be measured. The second limitation of the research was a delay time when taking the thermal images of the two selected case studies as the two buildings are located about 5 kilometres apart from each other. It caused about 10 minutes delay. While the other limitation is the two selected case studies are of different heights, as they are 11 and 16 stories tall respectively.

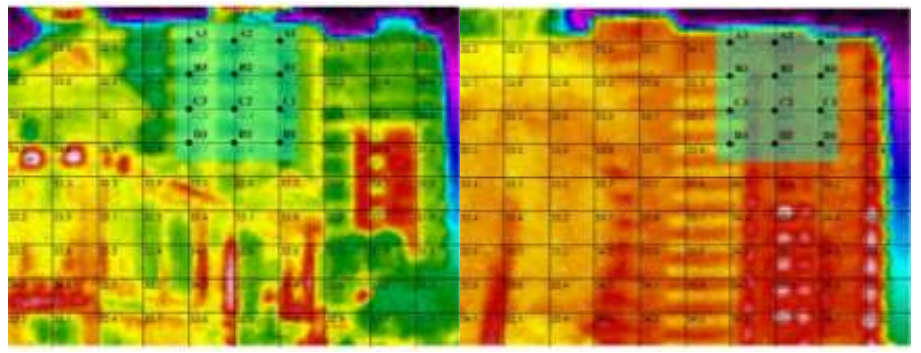

Fig. 6. The selected points of both case studies. (Left: Baystar. Right: The Light Linear)

As mentioned earlier, the thermal images were taken hourly for the two selected case studies from 12:00 to 6:00 $\mathrm{pm}$ on 15 th March. Figure 6 shows the facade selected points of both case studies. The resulting surface temperature for the selected points are shown in Table $1-3$ and Figure 7 as follows:

Table 1. The thermal images of the two selected case studies on $15^{\text {th }}$ March 2015.

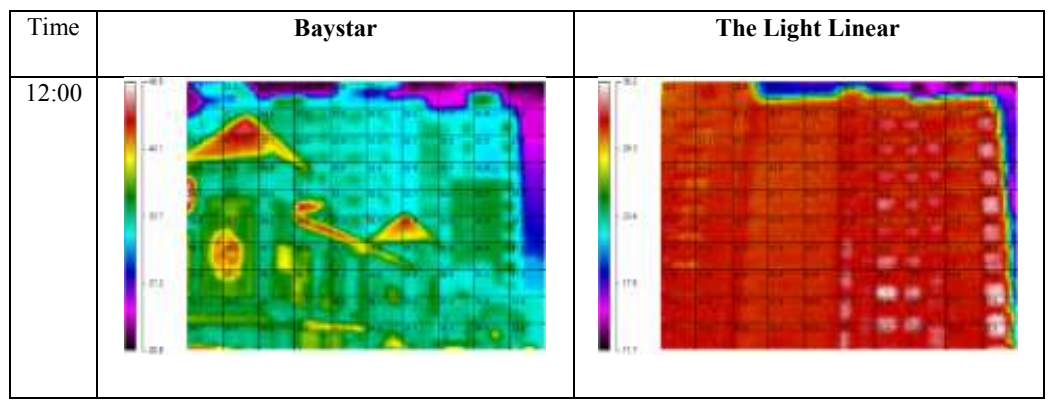




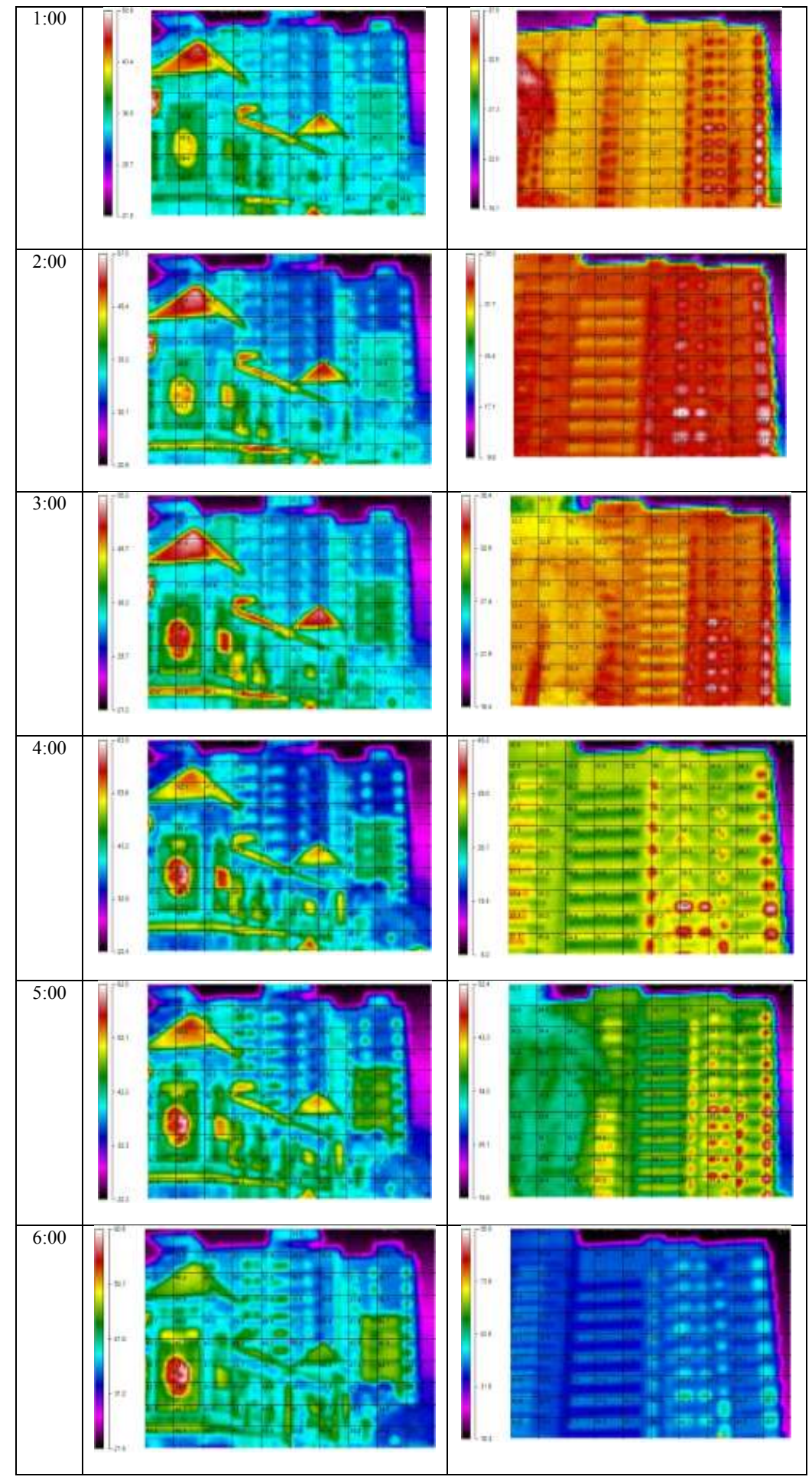


Table 2. The surface temperature of Mutiara Idaman 1 west façade selected points.

\begin{tabular}{|c|c|c|c|c|c|c|c|c|c|c|c|c|c|c|}
\hline \multirow{8}{*}{ ف․ } & \multirow{8}{*}{ 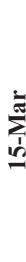 } & Rint & A1 & A2 & $\mathbf{A 3}$ & B1 & B2 & B3 & C1 & C2 & $\mathrm{C} 3$ & D1 & D2 & D3 \\
\hline & & 12:00 & 32.2 & 32.3 & 32.8 & 32.7 & 32.3 & 32.8 & 32.6 & 32.4 & 33 & 32.7 & 32.4 & 33.1 \\
\hline & & 1:00 & 32.3 & 32.5 & 33.2 & 33 & 32.7 & 33.1 & 32.8 & 32.9 & 33.4 & 32.8 & 32.8 & 33.7 \\
\hline & & 2:00 & 33.5 & 33.2 & 34.1 & 34.6 & 33.5 & 34.1 & 34.3 & 34 & 34.4 & 34.6 & 34.2 & 35.2 \\
\hline & & 3:00 & 33.4 & 33.6 & 34.5 & 35.4 & 33.9 & 34.4 & 35.3 & 34.2 & 34.6 & 35.3 & 34.4 & 35.2 \\
\hline & & 4:00 & 36.6 & 35.6 & 36.7 & 37.8 & 35.8 & 37 & 37.6 & 35.9 & 37.4 & 38.3 & 36.7 & 37.8 \\
\hline & & 5:00 & 37 & 36.5 & 38.1 & 39 & 36.5 & 37.7 & 38.7 & 36.7 & 38.5 & 38.8 & 37.3 & 39.4 \\
\hline & & 6:00 & 35.6 & 35.8 & 37.9 & 36.6 & 36 & 37.8 & 36.9 & 36.6 & 38.9 & 36.9 & 37.1 & 39.6 \\
\hline
\end{tabular}

Table 3. The surface temperature of The Light Linear west façade selected points.

\begin{tabular}{|c|c|c|c|c|c|c|c|c|c|c|c|c|c|c|}
\hline \multirow{8}{*}{ 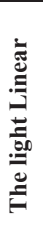 } & \multirow{7}{*}{ 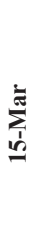 } & Rint & A1 & A2 & A3 & B1 & B2 & B3 & C1 & C2 & $\mathrm{C} 3$ & D1 & D2 & D3 \\
\hline & & 12:00 & 31.3 & 1.6 & 31.6 & 31.4 & 31.9 & 31.7 & 31.4 & 31.8 & 31.7 & 31.4 & 31.8 & 31.8 \\
\hline & & $1: 00$ & 32.9 & 33.3 & 32.9 & 32.9 & 33.3 & 33 & 33.1 & 33.6 & 33 & 33.1 & 3.3 & 33.1 \\
\hline & & 2:00 & 34.1 & 33.9 & 1.7 & 34.1 & 34.1 & 34.5 & 34 & 34.1 & 34.5 & 34.2 & 4.2 & 4.8 \\
\hline & & 3:00 & 34 & 34.5 & 34.2 & 33. & 34.2 & 33. & 34 & 34. & 34 & 34.2 & 34.3 & 34.1 \\
\hline & & 4:00 & 36.1 & 34.9 & 36.2 & 36. & 34.9 & 35.8 & 35.6 & 35.6 & 35.9 & 36 & 35.9 & 36.3 \\
\hline & & 5:0 & 38.2 & 39.3 & 38.7 & 38.6 & 39 & 38.5 & 39.3 & 40 & 38.7 & 39.3 & 39.5 & 38.9 \\
\hline & & 00 & 40 & 38.2 & 40.8 & 40.1 & 39 & 40.8 & 39.4 & 39.4 & 40.7 & 39.6 & 39.5 & 41.4 \\
\hline
\end{tabular}

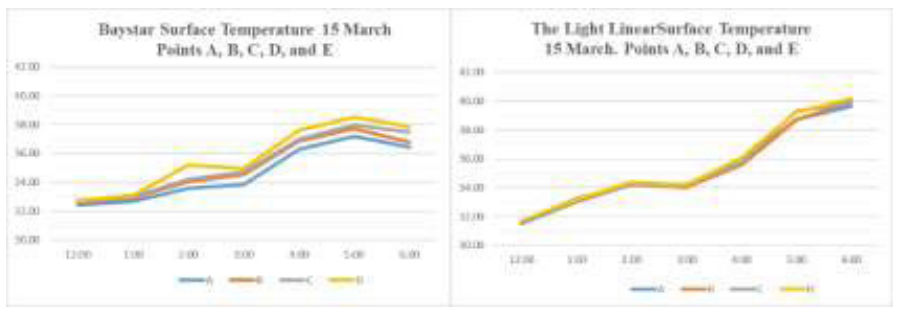

Fig. 7. The façade selected points' surface temperature of both case studies (Left: Baystar. Right: The Light Linear).

\section{DISCUSSION}

Figure 8 shows the average of façade surface temperature for both selected case studies, where the findings show that:

- Both Baystar and The Light Linear have similar temperature readings in most of the measurement hours.

- The highest temperature was at $6: 00 \mathrm{pm}$ at The Light Linear with $39.91^{\circ}$, while the lowest temperature was $31.62^{\circ}$ during the first hour.

- The lowest temperature measured at Baystar façade was $32.61^{\circ}$ at $12: 00 \mathrm{pm}$ and the highest temperature was $37.85^{\circ}$ at 5:00 pm.

- Comparing the results with average façade surface temperature of modern architectural style buildings (figure 9), the results show that the neo-minimalist style buildings have better shading performance. 


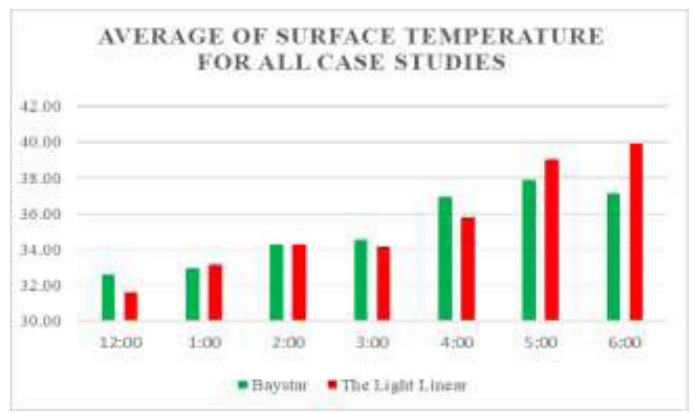

Fig. 8. The Average surface temperature of both case studies

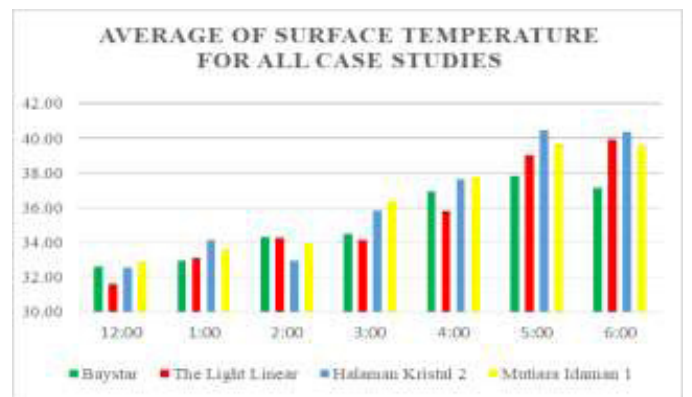

Fig. 9. The Average surface temperature of neo-minimalist and modern style buildings.

\section{CONCLUSION}

The research outcomes show that neo-minimalist architectural style is efficient, and it is able to provide good façade shading elements like wide balconies, recessed wall and preventing the unnecessary intense sunlight and solar radiation from increasing the indoor atmosphere temperature, and that will help to achieve the indoor thermal comfort. So, applying this architectural style will help to decrease the use of mechanical air conditioning for the thermal comfort. This research is the first step in the guide for designers and architects for their upcoming projects in order to design a building with efficient façade shading design.

\section{ACKNOWLEDGMENT}

The authors would like to express appreciation for the financial support under Research University Grant by Universiti Sains Malaysia.

\section{REFERENCES}

1. Y. Arab. "Facade Design Efficiency on Extent Sunlight Penetration in Neo-Minimalist Style Apartments in Penang, Malaysia", Journal of Architectural Engineering Technology, Vol. 4(2) (2015).

2. A. S. Hassan. Y. Arab, and Mazran Ismail. "Architectural Styles and Developments of Apartments in Putrajaya, Malaysia." (2015).

3. Tan, K. C., San Lim, H., MatJafri, M. Z., \& Abdullah, K. Landsat data to evaluate urban expansion and determine land use/land cover changes in Penang Island, Malaysia. Environmental Earth Sciences, 60(7), 1509-1521, 2010

4. Hoffman, A. v. High ambitions: The past and future of American low-income housing policy. Housing Policy Debate, 7(3), 423-446, (1996). 
5. Malaysia, D. o. (2010). Characteristics of Living Quarters 2010. Putrajaya: Department of Statistics Malaysia.

6. A. S. Hassan and M. Ramli, "Natural ventilation of indoor air temperature: A case study of the Traditional Malay House in Penang", American Journal of Engineering and Applied Sciences, pp. 521-528, (2010).

7. H. Feriadi and N. H. Wong, "Thermal comfort for naturally ventilated houses in Indonesia", Energy and Buildings, pp. 614-626, (2004).

8. M. S. Bakhlah and A. S. Hassan, "The study of air temperature when the sun path direction to ka'abah: with a case study of Al-Malik Khalid Mosque, Malaysia", International Transaction Journal of Engineering, Management \& Applied Sciences \& Technologies, pp. 185-202, (2012).

9. Rahman, A. M. Housing design in relation to environmental comfort: A comparison of the traditional Malay house and modern housing including work in the tripartite programme between Universiti Sains Malaysia, the Welsh School of Architecture and the UK building research. Building research and information, 23(1), 49-54, (1995).

10. Royle, K., \& Terry, C. Hawaiian Design: Strategies for Energy Efficient Architecture. Collingdale, Honolulus: DIANE Publishing, (1990).

11. K. M. Al-Obaidi, M. Ismail and A. M. A. Rahman, "A review of the potential of attic ventilation by passive and active turbine ventilators in tropical Malaysia", Sustainable Cities and Society, Vol.10, pp. 232-240, (2014).

12. A. S. Hassan, and Y. Arab. "Thermal Façade Surface Study on Early Modern Apartments in Kuala Lumpur". Journal of Built Environment, Technology and Engineering, Vol. 2 (2017).

13. Bezbabicheva, O. I., Bilchenko, A. V. and Kyslov, A. H. "Forecasting of Temperature Tension in Facade Beams of Bridge Constructions". Science and Transport Progress. Bulletin of Dnipropetrovsk National University of Railway Transport, 33, PP 28-31, (2010).

14. Badida, M., Dzuro, T., \& Franko, Š. Utilization infrared thermography in the automotive industry to determine faults by using thermal camera Fluke Ti10. Глобальне управління та економіка, 1, 7-13, (2015).

15. Županić, D., Bolarić, A., Stančić, M., Piljek, D., \& Jurinjak, B. (2015). Thermal imaging of the outer surface of the Laboratory for engines and vehicles at the Faculty of mechanical engineering and naval architecture. Interklima (2015). 